\title{
E COMMERCE AND ITS EFFECT ON THE RETAIL MARKET IN INDIA
}

\author{
'Sindhu Kumari P.R \\ *** Dr. Simmy Narula
}

\section{Introduction}

E-commerce is purchasing and selling of products and ventures over the internet. Before e-commerce purchasing and selling were done without internet physically in the markets however after the landing of e-commerce in India our life has become more convenient because of its number of advantages. The advantages offered by e-commerce are online shopping of anything whenever and at wherever, customers can discover the items on e-commerce websites which is no available in physical markets, it reduces cost and time, without stepping out from home we can get our item at home. Alongside ecommerce there is likewise a well known term called e-business due to which the business of enterprises has increased electronically with the help of internet by which they can reach to numerous customers which increases their sales. There is no specific definition of the terms Ecommerce and E-business, they are used interchangeably. Truth be told, E-commerce is a piece of E-business which focuses on external activities while E-business focuses on both internal and external activities of a business. Ecommerce has a great deal of good and awful effects on different areas. The key of having a successful ecommerce is to reduce the negative effects and increase the benefits at the same time.

E-Commerce remains for electronic commerce and caters to exchange of items, services and data through internet. Electronic commerce is more than simply purchasing and selling items online. It includes the entire online process of developing, marketing, selling, delivering, serving and paying for items and services. It is working together online. It includes any commercial movement that takes place directly between a business, its partners, or its customers through electronic correspondence and computerized data processing technology. E-Commerce is a modern business methodology that addresses the needs of the associations, merchants and consumers to cut expenses while enhancing the nature of merchandise and enterprises and increasing the speed of service delivery. India has demonstrated tremendous development in the E-Commerce segment. E-Commerce has become a vital apparatus for little and large businesses worldwide, not exclusively to sell to customers yet in addition to engage them. Despite the fact that the progress from conventional buying to online obtaining was very moderate at first in Indian market because of less number of internet users due to absence of internet office and awareness out in the open. Be that as it may, now the circumstance has changed and the e-commerce industry is developing quickly in our nation.

\section{Different Markets and Retailers in India}

\section{Markets}

- Physical Markets- Physical Market is a market where customers come physically in the market and face-to-face interact with the seller and buys the product and service in the exchange of money. Examples of physical markets are shopping malls, department stores etc.

- Non Physical Markets/Virtual Markets- NonPhysical Market is the market in which customers does not go physically to the seller and do not interact face-to-face. Customer buys the product on internet and exchange the money electronically. Examples of these markets are Flip kart, Amazon, eBay etc.

- Auction Market-Auction market is the market in which the goods are sold to the highest bidder and lower bidders are ignored.

- Market for Intermediate Goods-In these market raw materials are sold by using them final product is made

- $\quad$ Black Market - In these market illegal goods like drugs, weapons, and alcohol is sold which is supervised by illegal sellers.

- Knowledge Market-In this market Information and knowledge based products are sold.

- Financial Market- In this market liquid assets or money is exchanged. There are three types of financial markets: Stock market, in which stocks are exchanged; Bond market, in which Debt securities is exchanged in the form of the bond; Foreign exchange market, in which currency exchanges and it is also called currency market.

\section{Retailers}

- Department Store- Departmental store is a store which is a mix of multiple little stores under one organization which offers a wide variety of items. It includes value for the customers due to offer a wide variety of items at a place. 
- Supermarkets- Supermarkets generally sell nourishment and beverages however now due to customers need it additionally sell design, electronic related items. It has a decent purchasing power that why it sells at low prices.

- Warehouse Retailers- Warehouse retailers are situated at the place where the premises rent is very low with the goal that they can store, show and sell large measure of items.

- Specialty Retailers- Specialty Retailers sell a special service or item and provide expert knowledge and great service to customers. They include values by including accessories and related items in the same outlet.

\section{Review of Literature}

Menal Dahiya, (2017) Internet assumes a vital role in our every day life. We use internet day by day nearly for every single work. Before e-commerce purchasing and selling were done without internet physically in the markets however after the landing of e-commerce in India our life has become more convenient because of its number of advantages. Online shopping is a piece of ecommerce which is done for the most part by the users due to ecommerce websites in India which enables us to purchase and sell the items as indicated by our choice at affordable price. E-commerce website has a great deal of effects on different markets and retailers. In this paper we will examine about the different markets and retailers and effects of ecommerce on them.

Aparna Miglani, (2017) The purpose of this examination is to discover the influence and development of e-commerce and its effect on national and worldwide market. E-commerce is developing at a quick pace over the world. Its development and its benefits are already visible from the studies of developed countries but at the same time it's creation a positive effect in terms of development of developing countries. Due of globalization and relaxation in imports and exports between countries, economies over the world will witness better knowledge and data technology development .E-commerce is likewise assuming a critical role in higher revenue generation, improved customer base, larger measure of employment creation in Information Technology sector in a developing country.

Dr. Naveen Kumar, (2014) E-Commerce is the future of shopping. E-commerce is likewise one of the business choices that one should explore in future. E-Commerce is developing with quick pace in our nation. Backed by increasing internet users' base and favorable demographics, Indian ECommerce Industry has registered impressive development over the most recent couple of years. There are tremendous opportunities of development in E-Commerce in future too. Be that as it may, there are certain challenges which need to be addressed properly. In the present paper an attempt has been made to contemplate the present status of E-Commerce in India, examine the challenges of ECommerce and talk about the future of ECommerce in India.

Dr Mahesh, (2016) Electronic commerce normally known as e-commerce is exchanging items or services utilizing computer networks, for example, the internet. E-commerce draws on technologies, for example, mobile commerce, electronic store transfer, production network management, internet marketing, online exchange processing, EDI, inventory management system and automated information collection systems. The business model of the conventional retailers and ecommerce providers differ altogether. The essence of e-retailing is in its capacity to transcend physical boundaries and reach customers in a manner different from the customary retail stores to their very entryway steps. The developing e-commerce in India has its greater effect on the conventional retailers. To remain in the game, they have been chipping away at their internet strategies. The fundamental objective of the investigation is to understand the emerging trends of e-commerce and its development in Indian perspective. The effect of the e-commerce on physical or customary retail arranges. e-Commerce having the positive and negative influence on customary retail business.

Dr. V. V. Ravi Kumar, (2015) Online Retail in India is developing at a very quick pace in India. Even as it is developing it is beginning to cause disturbance to the conventional physical retail outlets and in addition making uneasiness established brands. This conceptual paper takes a gander at how online retail is steadily becoming a disruptive force in India. It threatens to upstage the customary retail also hurt a few best brands. These changes occurring in respect of Online Retail in India are highlighted by means of a series of disruptive incidents.

\section{E-Commerce and its Impact on Indian Market}

India is among the fastest developing economies of the world, as per several reports published by International Monetary Fund (IMF) and Central Statistics Office(CSO).The emergence of retail as a predominant market segment have contributed to the unprecedented development of e-commerce in India. For the budgetary year 2016-17 e-commerce sales reached US $\$ 16$ billion with a projection of a seven crease development inside the next two 
fiscals as estimated by Morgan Stanley. Furthermore, the e-commerce industry is expected to cross $\$ 120$ billion. The real driving variables for the development in e-commerce sector in India:

- $\quad$ Foreign Direct Investment.

- Goods and Services Tax

- Participation of niche companies in online exchanging

\section{Conclusion}

E-commerce involves an online exchange. Ecommerce provides multiple benefits to the consumers in type of accessibility of products at lower cost, wider choice and saves time. The general category of ecommerce can be broken down into two sections: E-Merchandise and Efinance. Numerous companies, associations, and communities in India are working together utilizing E-commerce and furthermore are receiving $\mathrm{M}$ commerce for working together. Ecommerce is indicating tremendous business development in India. Increasing internet users have added to its development. Despite being the second largest user base in world, just behind China (650 million, $48 \%$ of populace), the penetration of e-commerce is low compared to markets like the United States (266 M, $84 \%$ ), or France (54 M, 81\%), yet is developing at an unprecedented rate, including around 6 million new entrants every month. The business consensus is that development is at an inflection point. India's e-commerce market was worth about $\$ 3.9$ billion out of 2009 , it went up to $\$ 12.6$ billion of every 2013. In 2013, the e-retail segment was worth US $\$ 2.3$ billion. About $70 \%$ of India's e-commerce market is travel related. As indicated by Google India, there were 35 million online shoppers in India in 2014 Q1 and is expected to cross 100 million stamp by end of year 2016. By 2020, India is expected to generate $\$ 100$ billion online retail revenue out of which $\$ 35$ billion will apparel sales are set to grow four times in coming years. This paper is outcome of a review of different research studies carried out on Impact of E-commerce on Indian Commerce.

E-Commerce has made the shopping easy. The ECommerce Industry in India is developing quickly despites many challenge. E-commerce industry is one of the largest developing industries in India at present. The sale of ecommerce industry is expected to develop by very nearly 4 times by 2021 than the sales of 2015. This unprecedented development in E-Commerce is due to increase in PDAs and internet users, 3G/4G internet services, awareness out in the open, government initiative of digitalisation, advanced dispatching and payment choices, entry of foreign e-business players etc. Government should take steps to provide a proper legal framework so hurdles in the development of e-commerce are reduced to least.

Online retail is presently emerging as a powerful force in India. Their method for operations has taken the Indian customers by pleasant surprise as it comes with huge limits. Customary retailers are attempting to battle them out through different methods. A few of them are additionally joining the online fleeting trend as perhaps they see it just as the street ahead. To total the entire retail industry is expected to witness unexpected disturbances and perhaps combination.

\section{References}

1. Menal Dahiya, Study on E-Commerce and it's Impacts on Market and Retailers in India, Advances in Computational Sciences and Technology, Volume 10, Number 5, pp.14951500, 2017.

2. Aparna Miglani, E-COMMERCE AND ITS IMPACT ON INDIAN AND GLOBAL MARKET, International Research Journal of Engineering and Technology (IRJET), Volume: 04, Issue12, pp.78-83, 2017.

3. Dr. Naveen Kumar, E - Commerce in India: An Analysis of Present Status, Challenges and Opportunities, International Journal of Management Studies, vol.17, issue 9, pp.5667, 2014.

4. Dr Mahesh, A STUDY ON EMERGING TRENDS IN E-COMMERCE IN INDIA AND ITS IMPACT ON RETAIL INDUSTRY, ELK Asia Pacific Journals - Special Issue, vol.23, issue 3, pp.8-13, 2016.

5. Dr. V. V. Ravi Kumar, Online Retail in India A disruptive force, Journal of Asia Business Studies, Vol. 8, No. 1, pp. 43-64, 2015.

6. Shekhar Bellamkonda , "E-service quality: a study of online shoppers in India", American Journal of Business, Vol. 29, No. 2 pp. 178 188, 2014.

7. John Fernie, "The interface between retailers and logistics service providers in the online market", European Journal of Marketing, Vol. 45. No. 3 pp. 334 - 357, 2011. 